\title{
MÉTODOS DE OTIMIZAÇÃO GLOBAL APLICADOS NA BUSCA DOS PARÂMETROS SRC
}

\author{
Klaus Mairan Laurido do Carmo \\ Orientador: Dr. German Garabito Callapino (UFPA) \\ 69 p. - Dissertação (Mestrado) - Defesa 03.09.2004
}

\begin{abstract}
RESUMO 0 método de empilhamento por Superfície de Reflexão Comum (SRC) produz seções simuladas de afastamento nulo (AN) por meio do somatório de eventos sísmicos dos dados de cobertura múltipla contidos nas superfícies de empilhamento. Este método não depende do modelo de velocidade do meio, apenas requer 0 conhecimento a priori da velocidade próxima a superfície. A simulação de seções AN por este método de empilhamento utiliza uma aproximação hiperbólica de segunda ordem do tempo de trânsito de raios paraxiais para definir a superfície de empilhamento ou operador de empilhamento SRC. Para meios 2D este operador depende de três atributos cinemáticos de duas ondas hipotéticas (ondas $P I N$ e $N$ ), observados no ponto de emergência do raio central com incidência normal, que são: 0 ângulo de emergência do raio central com fonte-receptor nulo $\left(\beta_{0}\right), 0$ raio de curvatura da onda ponto de incidência normal $\left(R_{P I N}\right)$ e 0 raio de curvatura da onda normal $\left(R_{N}\right)$. Portanto, o problema de otimização no método SRC consiste na determinação, a partir dos dados sísmicos, dos três parâmetros $\left(\beta_{0}, R_{P I N}, R_{N}\right)$ ótimos associados a cada ponto de amostragem da seção AN a ser simulada. A determinação simultânea destes parâmetros pode ser realizada por meio de processos de busca global (ou otimização global) multidimensional, utilizando como função objetivo algum critério de coerência. 0 problema de otimização no método SRC é muito importante para 0 bom desempenho no que diz respeito a qualidade dos resultados e principalmente ao custo computacional, comparado com os métodos tradicionalmente utilizados na indústria sísmica. Existem várias estratégias de busca para determinar estes parâmetros baseados em buscas sistemáticas e usando algoritmos de otimização, podendo estimar apenas um parâmetro de cada vez, ou dois ou os três parâmetros simultaneamente. Levando em conta a estratégia de busca por meio da aplicação de otimização global, estes três parâmetros podem ser estimados através de dois procedimentos: no primeiro caso os três parâmetros podem ser estimados simultaneamente e no segundo caso inicialmente podem ser determinados simultaneamente dois parâmetros $\left(\beta_{0}, R_{P I N}\right)$ e posteriormente 0 terceiro parâmetro $\left(R_{N}\right)$ usando os valores dos dois parâmetros já conhecidos. Neste trabalho apresenta-se a aplicação e comparação de quatro algoritmos de otimização global para encontrar os parâmetros SRC ótimos, estes são: Simulated Annealing (SA), Very Fast Simulated Annealing (VFSA), Differential Evolution (DE) e Controlled Random Search - 2 (CRS2). Como resultados importantes são apresentados a aplicação de cada método de otimização e a comparação entre os métodos quanto a eficácia, eficiência e confiabilidade para determinar os melhores parâmetros SRC. Posteriormente, aplicando as estratégias de busca global para a determinação destes parâmetros, por meio do método de otimização VFSA que teve o melhor desempenho foi realizado o empilhamento SRC a partir dos dados Marmousi, isto é, foi realizado um empilhamento SRC usando dois parâmetros $\left(\beta_{0}, R_{P I N}\right)$ estimados por busca global e outro empilhamento SRC usando os três parâmetros $\left(\beta_{0}, R_{P I N}, R_{N}\right)$ também estimados por busca global.
\end{abstract}

ABSTRACT. The Common Reflection Surface Stack (CRS) method provides the simulation of zerooffset (Z0) sections by means of the summing seismic events of the multicoverage data contained in the stacking surface. This method does not depend on the velocity macro-model of medium; it only requires a priori knowledge of the near-surface velocity. The simulation of ZO sections for this stacking method uses a hyperbolic second-order traveltime approximation of the paraxial rays to define the CRS stacking surface or CRS stack operator. For 2D media, this operator depends on three kinematic attributes of two hypothetical waves $(N I P$ and $N$ waves), observed in the point of emergency of the central ray with normal incidence, namely, the angle of emergency of the central ZO ray $\left(\beta_{0}\right)$, the radius of curvature of the Normal Incidence Point Wave $\left(R_{N I P}\right)$ and the radius of curvature of the Normal Wave $\left(R_{N}\right)$. Therefore, the optimization problem in the CRS method consists in the determination, from the seismic data, of the three optimal parameters $\left(\beta_{0}, R_{N I P}, R_{N}\right)$ associated to each sample point of Z0 section to be simulated. The simultaneous determination of these parameters can be made by means of multidimensional global search process (or global optimization), using as objective function some coherence criterion. The optimization problem in CRS method is very important for the good performance with respect to quality of the results and mainly to computational cost, compared with the methods traditionally used in the seismic industry. There are several search strategies to determine these parameters, based on systematic searches and using optimization algorithms, where only one parameter at each time can be estimated, or the two or three parameters simultaneously. Taking in to account the search strategy by means of the application of global optimization, these three parameters can be estimated through of procedures: in the first case the three parameters can be simultaneously estimated and in second case initially two parameters can be determined simultaneously $\left(\beta_{0}, R_{N I P}\right)$, and subsequently the third parameter $\left(R_{N}\right)$, using the values of the two parameters already known. In this work it is presented the application and comparison of four algorithms of global optimization to find the CRS optimal parameters: Simulated Annealing (SA), Very Fast Simulated Annealing (VFSA), Differential Evolution (DE) and Controlled Random Search - 2 (CRS2). As importants results of the application of each optimization method, as well as between the methods regarding the effectiveness, efficiency and reliability to determine the best CRS parameters are presented. Subsequently, applying the global search strategies for the determination of these parameters, by means of the optimization method VFSA that presented the best performance, the CRS stacking was applied to the Marmousi dataset, one stacking using two parameters $\left(\beta_{0}, R_{N I P}\right)$, estimated by global search, and another CRS stacking using the three parameters $\left(\beta_{0}, R_{N I P}, R_{N}\right)$, also estimated by global search. 